\title{
STUDI KOMPARATIF KINERJA PORTOFOLIO SAHAM KELOMPOK PER TINGGI DAN KELOMPOK PER RENDAH DI BEI
}

\author{
Putu Agustina Dewi', \\ Ida Bagus Anom Purbawangsa ${ }^{2}$
}

${ }^{1}$ Fakultas Ekonomi dan Bisnis Universitas Udayana, Bali, Indonesia email: agustinadewi2323@yahoo.com

\begin{abstract}
ABSTRAK
Penelitian ini bertujuan untuk membandingkan kinerja portofolio saham kelompok PER tinggi dengan PER rendah pada industri manufaktur yang tercatat di Bursa Efek Indonesia. Populasi dalam penelitian ini adalah sebanyak 141 saham. Sampel yang digunakan adalah sebanyak 132 saham dengan menggunakan metode purposive sampling. Penelitian ini mengunakan analisis statistik uji beda dua rata-rata berpasangan dan independen. Berdasarkan hasil perbandingan indeks sharpe menunjukkan bahwa kinerja portofolio saham kelompok PER tinggi lebih baik dari kelompok $P E R$ rendah pada kondisi periode kepemilikan selanjutnya. Hasil uji beda menunjukkan tidak adanya perbedaan diantara kedua kinerja portofolio saham tersebut. Hasil penelitian ini diharapkan dapat menjadi bahan pertimbangan bagi investor saham dan manajer investasi untuk berinvestasi pada saham PER tinggi karena memberikan kinerja yang lebih baik.

Kata kunci: price earning ratio; metode indeks tunggal; indeks sharpe
\end{abstract}

\section{ABSTRACT}

This study aims to compare the performance of the high PER group stock portfolio with the performance of the low PER group stock portfolio in the manufacturing industry listed on the Indonesia Stock Exchange. The population in this study were 141 stocks. The sample used was 132 stocks using the purposive sampling method. This study uses descriptive statistical analysis and inferential statistics, namely different tests of two independent and dependent samples. Based on the results of the comparison sharpe index shows that the performance of the stock portfolio of the high PER group is better than the low PER group in the condition of the next ownership period. The results of different tests show no difference between the two performance of the stock portfolio. The results of this study are expected to be a consideration for stock investors and investment managers to invest in high PER stocks because it provide better performance.

Keywords: price earning ratio; single index method; sharpe index 


\section{PENDAHULUAN}

Kegiatan investasi di Indonesia saat ini sedang menarik perhatian masyarakat terutama investasi di pasar modal. Kemudahan berinvestasi di pasar modal tidak lepas dari perkembangan teknologi dan informasi yang cepat dan mudah sehingga menyebabkan meningkatnya minat masyarakat untuk berinvestasi terutama pada saham. Dikutip dari situs KSEI mencatat adanya peningkatan investor yang berinvestasi di pasar modal dari tahun 2012 sampai pertengahan tahun 2017.

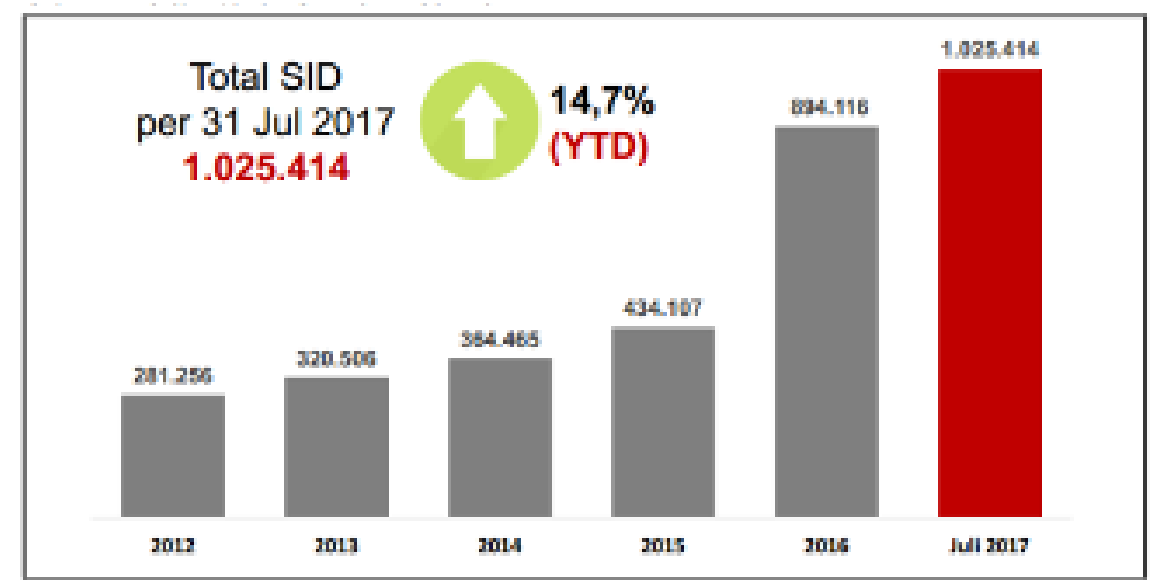

Gambar 1. Jumlah Investor di Indonesia Tahun 2012 - Juli 2017 Sumber: www.ksei.co.id, 2018

Jumlah Single Investor Identification (SID) meningkat 14,7 persen dari 894.116 per tahun 2016 menjadi 1.025 .414 per Juli tahun 2017. Berdasarkan data jumlah investor yang mengalami peningkatan dari tahun 2012 sampai pertengahan tahun 2017 menandai bahwa adanya sinyal positif bagi pasar modal Indonesia serta meluasnya pengetahuan masyarakat tentang investasi di pasar modal khususnya pada saham. Pasar modal dapat mendorong terciptanya alokasi dana yang efisien, karena dengan adanya pasar modal, investor dapat menginvestasikan dana tersebut pada perusahaan dengan harapan memperoleh keuntungan, sedangkan perusahaan dapat memanfaatkan dana tersebut untuk mendanai kegiatan operasional perusahaan (Tandelilin, 2010:26)

(Sunariyah, 2011:7) menyatakan pasar modal sebagai fasilitas untuk melakukan interaksi antara pembeli dan penjual, memberikan peluang bagi para pemegang saham untuk menentukan return yang diharapkan, memberikan kesempatan bagi investor untuk menjual kembali saham yang dimiliki, menciptakan kesempatan bagi masyarakat untuk berpartisipasi dalam perkembangan suatu perekonomian, dan menyediakan informasi yang akurat dan dapat dipercayai bagi pemodal.

Seorang investor membeli dan mempertahankan saham suatu perusahaan dengan harapan untuk memperoleh return berupa deviden maupun capital gain di masa yang akan datang (Sodikin \& Wuldani, 2016). Menghitung return saja tidak cukup, risiko dari investasi juga perlu diperhitungkan. Investor selalu berusaha untuk meminimalisir berbagai risiko yang timbul, baik yang bersifat jangka 
pendek ataupun jangka panjang. Investor yang rasional akan menginvestasikan dananya dengan memilih saham yang efisien, yang dapat memberikan return maksimal dengan risiko tertentu atau return tertentu dengan risiko minimal (Zubir, 2011:20).

Husnan (2001:317) mengemukakan bahwa jika kemampuan perusahaan untuk menghasilkan laba meningkat, maka harga saham akan meningkat. Dengan meningkatnya harga saham perusahaan, maka return saham yang akan diperoleh investor juga akan semakin tinggi. Investor perlu melakukan penilaian saham terlebih dahulu terhadap saham saham yang akan dipilihnya agar memperoleh keputusan investasi yang tepat sehingga menghasilkan return yang diharapkan. Penilaian saham yang menghasilkan informasi nilai intrinsik selanjutnya akan dibandingkan dengan harga pasar saham untuk menentukan posisi jual atau beli terhadap suatu saham perusahaan (Tandelilin, 2010).

Nazwirman (2008) menyatakan pendekatan PER merupakan salah satu pendekatan yang populer di kalangan analisis dan praktisi saham dalam penilaian investasi saham. PER merupakan ukuran untuk menentukan bagaimana pasar memberi nilai atau harga pada saham perusahaan. $P E R$ mengindikasikan mood investor saat ini, yang menunjukkan seberapa besar mereka bersedia membayar per unit pendapatan perusahaan. Rasio ini menunjukkan seberapa besar investor menilai harga dari saham terhadap kelipatan earnings (Anung dkk., 2016). Harga pasar saham dan earning per share menentukan nilai rasionya. PER meningkat ketika investor bersedia membayar lebih per unit pendapatan sementara pendapatan tetap stabil (Sezgin, 2010). PER yang tinggi juga menyiratkan tingkat pertumbuhan yang tinggi karena tingkat pertumbuhan berhubungan positif dengan harga (Huang \& Wirjanto, 2012).

Singgih (2012) dan Permata dkk. (2013) menyatakan bahwa penilaian saham dengan menggunakan PER merupakan pendekatan yang lebih mendekati nilai riil harga pasar saham. Chen et al. (2015) menyatakan penilaian saham harus mempertimbangkan pendapatan di masa depan karena dengan berinvestasi dalam saham dengan PER di masa depan yang relatif tinggi, signifikan dapat diperoleh risk adjusted return yang yang lebih tinggi daripada investasi dalam saham dengan PER masa lalu yang relatif tinggi. Sodikin \& Wuldani (2016) menyatakan bahwa semakin tinggi nilai $P E R$ maka harga saham perusahaan akan semakin mahal dan sebaliknya semakin rendah nilai PER makan semakin rendah harga saham perusahaan. Alasan investor atau calon investor melakukan analisis saham dengan PER, dikarenakan adanya keinginan akan hasil (return) yang layak dari suatu investasi saham (Suryanto, 2016).

Informasi menjadi suatu instrumen yang sangat mempengaruhi tindakan yang akan diambil seorang investor untuk meramalkan kondisi pasar, baik informasi buruk (bad news) maupun informasi baik (good news). Investor yang berlaku tidak rasional dengan memberikan reaksi yang sangat berlebihan (overreaction) dalam menanggapi informasi yang diterimanya, cenderung menetapkan saham dengan $P E R$ tinggi sebagai reaksi terhadap berita yang dianggap "baik" dan saham dengan $P E R$ rendah sebagai reaksi terhadap berita yang dianggap "buruk". Hingga pada akhirnya investor menyadari telah bereaksi secara berlebihan menyebabkan pembalikan harga ke arah yang berlawanan. 
Pembalikan ini ditunjukkan oleh turunannya harga saham secara drastis yang sebelumnya berpredikat baik atau naiknya harga saham yang sebelumnya berpredikat buruk (Sukmawati \& Kowanda, 2017). Investor serta manajer yang menginginkan pengembalian saham yang tinggi harus memiliki keterampilan pemilihan saham yang baik dan mampu menentukan waktu yang tepat untuk membeli atau menjual saham tersebut (Zabiulla, 2014).

Terjadinya fenomena reaksi berlebihan ini memungkinkan investor melakukan strategi membeli saham pada waktu menjadi PER rendah dan menjualnya pada saat saham tersebut berbalik menjadi PER tinggi. Strategi membeli saham pada saat PER rendah karena saham undervalued atau murah, menyebabkan investor melakukan reaksi beli lebih banyak dibandingkan dengan reaksi jual, sehingga mengakibatkan return saham menurun pada periode berikutnya. Sebaliknya strategi menjual saham pada saat $P E R$ tinggi karena saham overvalued atau mahal, menyebabkan investor melakukan reaksi jual lebih banyak dibandingkan dengan reaksi beli, sehingga mengakibatkan return saham menurun pada periode berikutnya. (Wiagustini, 2008).

Bodie et al. (2014) mengatakan bahwa ada dua langkah yang harus dilakukan dalam proses investasi saham. Pertama, melakukan analisis terhadap return dan risiko saham-saham yang akan dimasukkan ke dalam portofolio. Kedua adalah membentuk portofolio optimal dari saham-saham yang dipilih. Aktivitas ini meliputi mengalokasikan dana, dan menghitung return dan risiko berbagai portofolio, dan memilih portofolio yang terbaik. Strategi investasi portofolio saham yang menghasilkan pembalikan (reversal) return disebut strategi investasi kontrarian. Strategi investasi kontrarian, pertama kali ditemukan oleh Bondt \& Thaler (1985) yang menggunakan data pasar modal Amerika Serikat. Penelitian tersebut menemukan hasil bahwa saham-saham yang pada mulanya memberikan tingkat return positif atau negatif akan mengalami pembalikan (reversal) pada periode-periode berikutnya.

Hartono (2017:333) menyatakan bahwa untuk mengurangi risiko investasi, maka investor dapat berinvestasi dalam berbagai jenis saham dengan membentuk portofolio saham. Portofolio saham adalah strategi investasi dalam berbagai jenis saham dengan tujuan menyebarkan sumber perolehan return dan kemungkinan risiko (Samsul, 2006). Hal ini dilakukan dengan harapan jika nilai salah satu saham menurun maka nilai saham yang lain tidak akan ikut turun, atau bahkan naik. Strategi tersebut diharapkan dapat membantu investor dalam melakukan penyebaran risiko investasi tanpa harus mengorbankan return yang diharapkan (Rachman \& Febrianto, 2012).

Identifikasi terhadap sekuritas-sekuritas mana yang akan dipilih serta berapa proporsi dana yang akan ditanamkan pada masing-masing sekuritas merupakan tahap penting dalam analisis sekuritas. Pemilihan jumlah sekuritas dimaksudkan untuk mengurangi risiko yang ditanggung oleh investor (Gunawan \& Artini, 2016). Penentuan portofolio optimal dalam penelitian ini menggunakan model indeks tunggal karena model ini dapat menyederhanakan perhitungan di model Markowits. Model indeks tunggal juga dapat menghitung return ekspektasian dan risiko portofolio (Hartono, 2017:427). Model Indeks Tunggal dapat memberikan gambaran kepada investor terkait saham portofolio optimal, proporsi dana, tingkat 
return dan risiko saham yang harus ditanggung oleh investor (Sari \& Nuzul, 2017).

Analisa kinerja portofolio bertujuan untuk mengevaluasi portofolio yang telah dibentuk, yaitu untuk mengetahui apakah return portofolio yang telah dibentuk mampu memberikan return di atas return portofolio lainnya yang dijadikanm benchmark dan mengevaluasi apakah return yang diperoleh sudah sesuai dengan tingkat risiko yang harus ditanggung (Supriyanto \& Yani, 2014). Penelitian ini menggunakan indeks Sharpe sebagai ukuran kinerja, karena indeks Sharpe tepat digunakan untuk mengukur portofolio saham yang kurang terdiversifikasi dengan baik (Saputro \& Badjra, 2016). Indeks Sharpe adalah ukuran kinerja portofolio optimal yang paling banyak digunakan oleh akademisi maupun praktisi karena kekuatan hasil serta kesederhanaan hasil pengukurannya. Sharpe memeringkat beberapa portofolio berdasarkan kinerjanya, dimana semakin tinggi indeks Sharpe suatu portofolio dibandingkan dengan portofolio lainnya, maka semakin baik kinerja portofolio tersebut (Levy, 2017).

Fenomena overreaction yang menyebabkan terjadinya reversal return saham $P E R$ tinggi dengan $P E R$ rendah menyebabkan kinerja portofolio kelompok saham $P E R$ rendah yang mengalahkan portofolio kelompok saham $P E R$ tinggi (Wiagustini, 2008). Penelitian empiris mengenai perbandingan kinerja portofolio kelomok saham PER tinggi dan PER rendah pertama kali dilakukan oleh Basu $(1977,1983)$ di New York Stock Exchange (NYSE) yang hasilnya mengarah pada reversal return yaitu kelompok saham dengan $P E R$ rendah periode berikutnya outperform dengan return kelompok saham PER tinggi.

Peneliti lainnya juga meneliti hal yang sama antara lain: Rathnasekara (2017) di Sri Lanka; Alajbeg et al. (2016) di Kroasia; Chhaya \& Nigam (2015), Druv \& Raval (2015), Bodhanwala (2014), dan Lakshmi \& Roy (2013) di India; Kelly \& Mcclean (2008) di Australia; Astiti (2014), Fun \& Basana (2010), dan Wiagustini (2008) di Indonesia yang menunjukkan portofolio saham yang dibentuk dari PER tinggi mempunyai korelasi return yang tinggi namun memiliki kinerja yang menurun untuk periode berikutnya; sebaliknya portofolio saham yang dibentuk dari PER rendah mempunyai korelasi return yang rendah namun memiliki kinerja yang meningkat untuk periode berikutnya. Namun, Mustakawarman dkk. (2016) melakukan penelitian mengenai perbandingan kinerja portofolio saham PER tinggi (overvalued) dengan PER rendah (undervalued) menyatakan bahwa kinerja portofolio saham PER rendah mengalami penurunan kinerja pada periode berikutnya, sedangkan portofolio saham PER tinggi mengalami peningkatan pada periode berikutnya.

Periode pengukuran kinerja portofolio saham dalam penelitian ini menggunakan periode formasi dan periode kepemilikan selanjutnya 12 bulan. Penggunaan 12 bulan pada periode formasi dan periode kepemilikan selanjutnya karena pada umumnya investor melihat data-data historis tahun sebelumnya yang dapat dijadikan sebagai acuan dalam membentuk portofolio saham. Periode tersebut dapat memberikan informasi yang mendalam kepada investor tentang periode waktu membeli, menahan, dan menjual saham. 
Penelitian empiris yang mendukung deskripsi teori mengenai perbandingan kinerja portofolio saham kelompok $P E R$ tinggi dengan kinerja portofolio saham kelompok $P E R$ rendah dalam investasi portofolio saham, antara lain:

Lakshmi \& Roy (2013) menyatakan bahwa portofolio dengan PER yang tinggi menghasilkan rata-rata return negatif. Sedangkan portofolio dengan $P E R$ rendah memberikan hasil tahunan positif. Hal ini sejalan dengan penelitian yang dilakukan oleh Druv \& Raval (2015) di India yaitu National Stock Exchange (NSE) selama 5 tahun yang mendapatkan hasil bahwa sekuritas dengan PER yang rendah memberikan return yang lebih tinggi daripada sekuritas dengan $P E R$ yang tinggi. Houmes \& Chira (2014) menyatakan bahwa saham dengan PER rendah menghasilkan return yang lebih tinggi dalam jangka waktu panjang dan sebaliknya, namun apabila kepemilikan orang dalam tinggi return saham PER rendah menurun sedangkan return saham PER tinggi meningkat.

Chhaya \& Nigam (2015) yang melakukan penelitian mengenai penilaian kinerja saham di pasar modal India yaitu Bombay Stock Exchange (BSE) dengan pendekatan PER dari tahun 2000 - 2013 yang menemukan hasil bahwa kinerja saham dengan $P E R$ rendah mengungguli kinerja saham dengan PER tinggi. Hasil penelitian serupa juga diperoleh Alajbeg et al. (2016) melakukan penelitian di pasar modal Kroasia yang hasilnya menunjukkan bahwa kinerja portofolio saham $P E R$ yang lebih rendah mengalahkan kinerja portofolio saham dengan PER yang lebih tinggi.

Bodhanwala (2014) melakukan penelitian yang sama di India yang berfokus pada membangun portofolio berdasarkan $P E R$ dan mengukur kinerjanya selama 10 tahun terakhir (2002-2012), menunjukkan bahwa investasi mengunakan saham dengan nilai $P E R$ rendah akan menghasilkan keuntungan yang lebih tinggi dibandingkan dengan berinvestasi pada saham dengan nilai PER tinggi. Hasil penelitian ini sama dengan penelitian yang dilakukan Kelly \& Mcclean (2008) yang menyatakan portofolio $P E R$ rendah menghasilkan tingkat pengembalian lebih tinggi daripada portofolio $P E R$ tinggi. Dalam penelitiannya ditemukan bahwa saham dengan laba negatif juga berkinerja cukup baik. Astiti (2014) menyatakan bahwa permintaan meningkat untuk portofolio saham $P E R$ rendah dan permintaan menurun untuk portofolio saham $P E R$ tinggi yang akhirnya berdampak return dan juga kinerja portofolio periode berikutnya meningkat untuk portofolio saham PER rendah dan menurun untuk portofolio saham PER tinggi. Penelitian oleh Fun \& Basana (2010) di pasar modal Indonesia selama periode 2005-2010 menunjukkan bahwa terdapat perbedaan yang signifikan antara kinerja potofolio PER rendah dan kinerja portofolio PER tinggi dalam jangka pendek (holding period 6 bulan) tetapi tidak ada perbedaan yang signifikan antara kedua portofolio return saham jika mereka bertahan selama satu, dua, tiga, dan empat tahun.

Berdasarkan deskripsi teori dan hasil penelitian terdahulu yang telah diuraikan sebelumnya, maka hipotesis yang diajukan dalam penelitian ini yaitu:

$\mathrm{H}_{1}$ : Terdapat perbedaan signifikan antara kinerja portofolio kelompok saham $P E R$ tinggi pada periode formasi dengan kinerja portofolio kelompok saham PER tinggi pada periode kepemilikan selanjutnya. 
$\mathrm{H}_{2}$ : Terdapat perbedaan signifikan antara kinerja portofolio kelompok saham PER Ratio rendah pada periode formasi dengan kinerja portofolio kelompok saham $P E R$ rendah pada periode kepemilikan selanjutnya.

$\mathrm{H}_{3}$ : Terdapat perbedaan signifikan antara kinerja portofolio kelompok saham PER tinggi dengan kinerja portofolio kelompok saham PER rendah pada kondisi periode formasi.

$\mathrm{H}_{4}$ : Terdapat perbedaan signifikan antara kinerja portofolio kelompok saham PER tinggi dengan kinerja portofolio kelompok saham PER rendah pada kondisi periode kepemilikan selanjutnya.

Penelitian ini merupakan penelitian komparatif yang membandingkan kinerja portofolio saham kelompok PER tinggi dan kelompok PER rendah pada periode formasi dan periode kepemilikan selanjutnya pada industri manufaktur di BEI selama periode 2014-2017. Kerangka konseptual dari penelitian ini dapat dilihat pada Gambar 2.

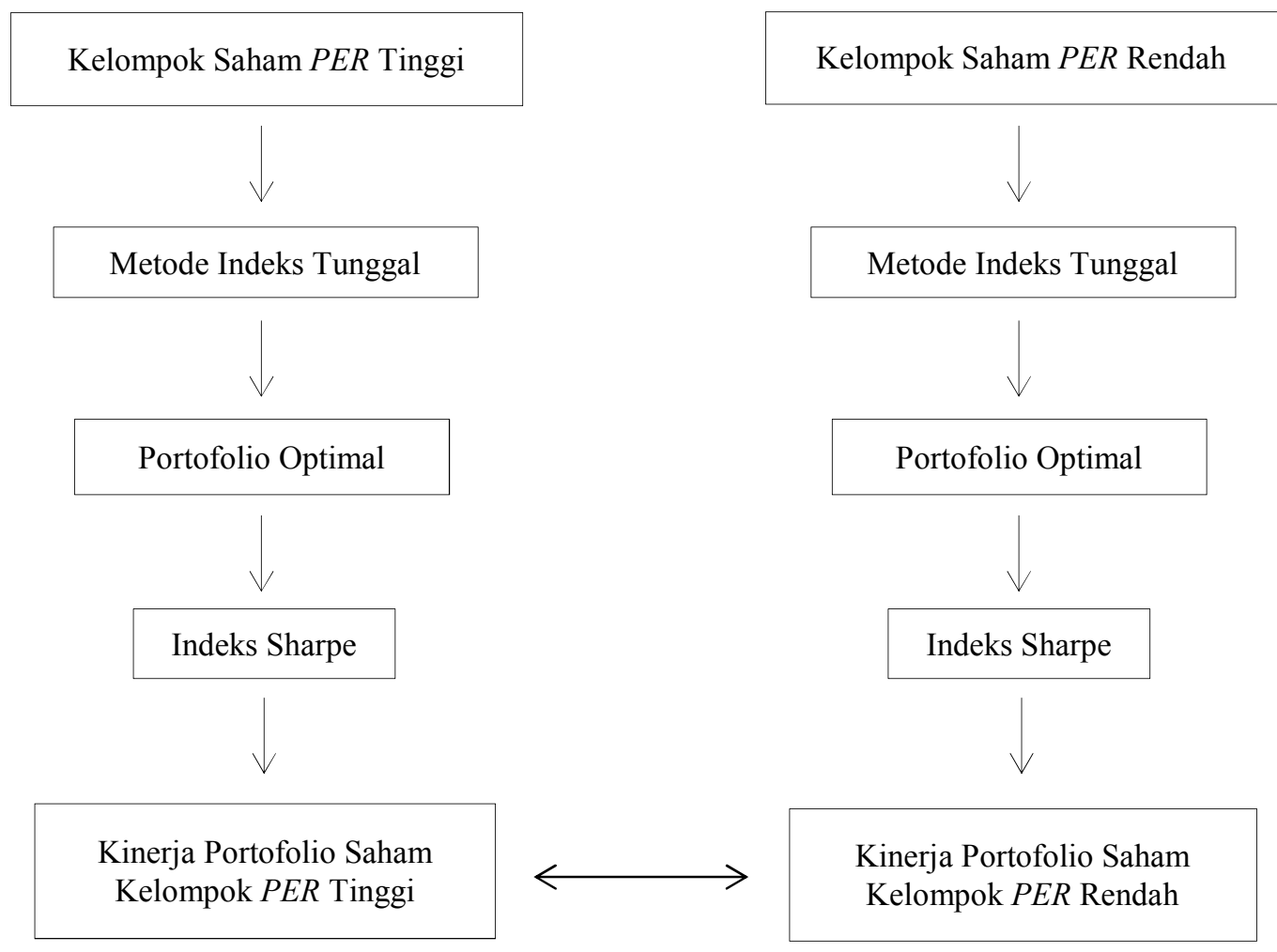

Gambar 2. Kerangka Konseptual

\section{METODE PENELITIAN}

Desain penelitian yang digunakan pada penelitian ini adalah desain penelitian komparatif yang membandingkan kinerja antara portofolio saham $P E R$ tinggi dengan portofolio PER rendah dibentuk dengan metode Indeks Tunggal yang diukur kinerjanya dengan risk adjusted return (Indeks Sharpe). 
Populasi penelitian ini adalah seluruh saham perusahaan yang tercatat di Industri Manufaktur dari tahun 2014-2017 yang berjumlah 141 saham. Sampel adalah bagian dari jumlah dan karakteristik yang dimiliki oleh populasi (Sugiyono, 2017:167). Sampel yang digunakan dalam penelitian ini diambil secara purposive sampling. Adapun kriteria sampel dalam penelitian ini adalah sebagai berikut: pertama, saham perusahaan pada Industri Manufaktur yang aktif selama periode 2014-017. Berdasarkan kriteria ini diperoleh 132 saham. Kedua, saham perusahaan pada Industri Manufaktur yang memiliki nilai PER diatas ratarata $(P E R>94,85)$ termasuk kedalam kelompok $P E R$ tinggi. Berdasarkan kriteria ini diperoleh 42 saham. Ketiga, saham perusahaan pada Industri Manufaktur yang memiliki nilai $P E R$ dibawah rata-rata $(P E R<94,85)$ termasuk kedalam kelompok $P E R$ rendah. Berdasarkan kriteria ini diperoleh 90 saham.

Penelitian ini menggunakan metode pengumpulan data berupa metode observasi non partisipan.Data kuantitatif dalam penelitian ini adalah harga saham perusahaan Industri Manufaktur yang terdaftar di Bursa Efek Indonesia salam periode tahun 2014-2017. Data sekunder dalam penelitian ini adalah laporan keuangan perusahaan, harga saham penutupan, tingkat bunga Sertifikat Bank Indonesia (SBI), indeks harga saham gabungan (IHSG). Data laporan keuangan perusahaan digunakan untuk mengelompokkan saham ke dalam portofolio saham PER tinggi dan PER rendah yang diperoleh dari situs www.idx.co.id. Data harga saham penutupan digunakan untuk menghitung return saham yang diperoleh dari www.finance.yahoo.com. Data tingkat bunga Sertifikat Bank Indonesia (SBI) digunakan untuk menghitung return bebas risiko yang diperoleh dari website Bank Indonesia www.bi.go.id. Sedangkan data IHSG digunakan untuk menghitung return pasar yang diperoleh dari www.finance.yahoo.com. Data yang dikumpulkan adalah data-data selama periode 2014-2017.

Portofolio saham kelompok PER tinggi dan kelompok PER rendah adalah portofolio saham yang dibentuk dari seluruh saham yang masuk dalam kelompok $P E R$ tinggi dan kelompok PER rendah yang tercatat pada industri manufaktur di Bursa Efek Indonesia (BEI) selama periode 2014-2017. Langkah-langkah dalam pembentukan portofolio ini yaitu yang pertama, mengurutkan semua sahamsaham perusahaan yang tercatat pada Industri Manufaktur berdasarkan dengan nilai $P E R$. Kedua, mengelompokkan saham-saham yang telah diurutkan menjadi dua kelompok yaitu kelompok saham $P E R$ tinggi dan saham $P E R$ rendah. Kelompok saham yang memiliki nilai $P E R$ diatas rata-rata merupakan kelompok saham $P E R$ tinggi yaitu sebanyak 42 saham, sedangkan kelompok saham yang memiliki nilai $P E R$ dibawah rata-rata merupakan kelompok saham $P E R$ rendah yaitu sebanyak 90 saham. Ketiga, membentuk portofolio saham kelompok PER tinggi dan kelompok PER rendah dengan metode Indeks Tunggal.

Return saham kelompok PER tinggi dan PER rendah adalah tingkat pengembalian bulanan dari saham-saham yang masuk ke dalam portofolio saham kelompok PER tinggi dan PER rendah pada Industri Manufaktur periode 20142017 yang diukur dengan formula:

$R_{i t}=\frac{P_{i t}-P_{i t-1}}{P_{i t-1}}$ 
Return pasar adalah tingkat pengembalian bulanan dari indeks pasar pada BEI yang diukur dengan formula:

$R_{m t}=\frac{I_{t}-I_{t-1}}{I_{t-1}}$

Beta saham kelompok $P E R$ tinggi dan $P E R$ rendah merupakan sensitivitas return saham kelompok PER tinggi dan PER rendah terhadap return pasar pada Industri Manufaktur periode 2014-2017 yang diukur dengan formula:

$\beta_{i}=\frac{\sum_{t=1}^{n}\left(R_{i t}-\bar{R}_{i t}\right)\left(R_{m t}-\bar{R}_{m t}\right)}{\sum_{t=1}^{n}\left(R_{m t}-\bar{R}_{m t}\right)^{2}}$

Alpha saham kelompok $P E R$ tinggi dan $P E R$ rendah adalah nilai ekspektasian dari return saham kelompok PER tinggi dan PER rendah terhadap return pasar yang diukur dengan formula:

$\alpha_{i}=E\left(R_{i}\right)-\left(\beta_{i} R_{m t}\right)$

Kesalahan residu kelompok PER tinggi dan PER rendah adalah tingkat kesalahan estimasi nilai return ekspektasian yang diukur dengan formula:

$e_{i}=E\left(R_{i t}\right)-\alpha_{i t}-\left(\beta_{i t} R_{m t}\right)$

Variance pasar adalah risiko unik atau risiko tidak sistematik dari return pasar dapat diukur dengan formula:

$\sigma_{m t}^{2}=\frac{\sum_{t=1}^{n}\left(R_{m t}-\bar{R}_{m t}\right)^{2}}{n-1}$

Variance kesalahan residu adalah risiko unik atau risiko tidak sistematik dari saham kelompok PER tinggi dan kelompok PER rendah yang dapat diukur dengan formula:

$\sigma^{2}{ }_{e i}=\frac{\sum_{t=1}^{n}\left(e_{i}-\bar{e}_{i}\right)^{2}}{n-1}$

Excess Return to Beta adalah pengukuran untuk menunjukkan hubungan antara return dan risiko yang dapat diukur dengan formula:

$E R B=\frac{E\left(R_{i}\right)-R f}{\beta_{i}}$

Cut of Rate dapat diukur dengan formula:

$C_{i}=\frac{\sigma_{m}^{2} \sum_{i=1}^{n} A_{i}}{1+\sigma_{m}^{2} \sum_{i=1}^{n} B_{i}}$

Proporsi masing masing alokasi dana masing masing saham dapat diukur dengan formula:

$$
W_{i}=\frac{X_{i}}{\sum_{i=1}^{k} X_{i}}
$$

Return ekspektasi portofolio dapat diukur dengan formula: 
$E\left(R_{p}\right)=\sum_{i=1}^{k} W_{i} \cdot E\left(R_{i}\right)$

Variance portofolio adalah risiko tidak sistematik portofolio yang dapat diukur dengan formula:

$\sigma^{2}{ }_{p}=\left(\sum_{i=1}^{n} W_{i} \cdot \beta_{i}\right)^{2} \cdot \sigma_{m}{ }^{2}+\left(\sum_{i=1}^{n} W_{i} \cdot \sigma_{e i}\right)^{2}$

Kinerja portofolio saham kelompok $P E R$ tinggi dan $P E R$ rendah adalah indeks Sharpe dari saham-saham yang masuk ke dalam portofolio saham kelompok PER tinggi dan PER rendah pada Industri Manufaktur periode 20142017 yang dihitung dengan formula:

$\widehat{S_{P l}}=\frac{\overline{R_{P l}}-\overline{R F}}{\widehat{\sigma_{T R}}}$

Risk adjusted return portofolio saham kelompok PER tinggi dan kelompok $P E R$ rendah merupakan pengukuran kinerja portofolio yang telah memasukkan faktor risiko, dimana dalam penelitian ini menggunakan indeks Sharpe. Pengukuran indeks Sharpe portofolio saham kelompok PER tinggi dengan PER rendah menggunakan Formula 13.

Teknik analisis statistik uji beda dua rata-rata berpasangan digunakan untuk menguji signifikansi perbedaan kinerja portofolio saham kelompok PER tinggi periode formasi dengan periode kepemilikan selanjutnya dan menguji signifikansi perbedaan kinerja portofolio saham kelompok PER rendah pada periode formasi dengan periode kepemilikan selanjutnya. Rumus pengujian dengan menggunakan statistik uji beda dua rata-rata berpasangan adalah sebagai berikut:

$$
t=\frac{\overline{X_{1}}-\overline{X_{2}}}{\sqrt{\frac{S_{1}^{2}}{n_{1}}+\frac{S_{2}^{2}}{n_{2}}-2 r\left(\frac{S_{1}}{\sqrt{n_{1}}}\right)\left(\frac{S_{2}}{\sqrt{n_{2}}}\right)}}
$$

Keterangan:

$\overline{X_{1}} \quad=$ rata-rata kinerja portofolio saham kelompok $P E R$ tinggi dan $P E R$ rendah periode formasi

$\overline{X_{2}} \quad=$ rata-rata kinerja portofolio saham kelompok $P E R$ tinggi dan $P E R$ rendah periode kepemilikan selanjutnya

$S_{1} \quad$ = simpangan baku portofolio saham kelompok PER tinggi dan PER rendah periode formasi

$S_{2} \quad$ = simpangan baku portofolio saham kelompok PER tinggi dan PER rendah periode kepemilikan selanjutnya

$n_{1} \quad=$ jumlah sampel kinerja portofolio saham kelompok PER tinggi dan PER rendah periode formasi

$n_{2} \quad=$ jumlah sampel kinerja portofolio saham kelompok $P E R$ tinggi dan $P E R$ rendah periode formasi

$r \quad=$ korelasi antara kinerja portofolio saham kelompok PER tinggi dan PER 
rendah periode formasi dengan periode kepemilikan selanjutnya

Teknik analisis statistik uji beda dua rata-rata independen digunakan untuk menguji signifikansi perbedaan kinerja portofolio saham kelompok PER tinggi dan kelompok $P E R$ rendah pada periode formasi dan kepemilikan selanjutnya. Rumus pengujian dengan menggunakan statistik uji beda dua rata-rata independen adalah sebagai berikut:

$$
t=\frac{\overline{X_{1}}-\overline{X_{2}}}{\sqrt{\frac{1}{2}\left(S_{1}^{2}+S_{2}^{2}\right)} \cdot \sqrt{\frac{2}{n}}}
$$

Keterangan:

$\overline{X_{1}} \quad=$ rata-rata kinerja portofolio saham kelompok PER tinggi periode formasi dan kepemilikan selanjutnya

$\overline{X_{2}} \quad=$ rata-rata kinerja portofolio saham kelompok PER rendah periode formasidan kepemilikan selanjutnya

$S_{1} \quad=$ simpangan baku portofolio saham kelompok PER tinggi periode formasi dan kepemilikan selanjutnya

$S_{2} \quad=$ simpangan baku portofolio saham kelompok PER tinggi periode formasi dan kepemilikan selanjutnya

$n \quad=$ jumlah sampel

\section{HASIL PENELITIAN DAN PEMBAHASAN}

Portofolio saham kelompok PER tinggi periode formasi dan portofolio saham kelompok PER tinggi periode kepemilikan selanjutnya selama tahun 20142017 meliputi tiga kali observasi. Observasi pertama dimulai pada tahun 2014 yang membandingkan kinerja portofolio dengan melihat indeks Sharpe portofolio saham kelompok PER tinggi tahun 2014 periode formasi dengan portofolio saham kelompok $P E R$ tinggi tahun 2015 periode kepemilikan selanjutnya, dilanjutkan hingga observasi terakhir pada tahun 2017.

Portofolio saham kelompok PER rendah periode formasi dan portofolio saham kelompok $P E R$ rendah periode kepemilikan selanjutnya selama tahun 2014-2017 meliputi tiga kali observasi. Rincian periode observasi dapat dilihat pada Tabel 1.

Tabel 1.

Tabel Observasi Periode Formasi dan Periode Kepemilikan Selanjutnya Portofolio Saham kelompok PER dan kelompok PER rendah Tahun 20142017

\begin{tabular}{ccc}
\hline \multirow{2}{*}{ Observasi } & \multicolumn{2}{c}{ Periode Observasi } \\
& Periode Formasi & $\begin{array}{c}\text { Periode Kepemilikan } \\
\text { Selanjutnya }\end{array}$ \\
\hline 1 & Januari-Desember 2014 & Januari-Desember 2015 \\
2 & Januari-Desember 2015 & Januari-Desember 2016 \\
3 & Januari-Desember 2016 & Januari-Desember 2017 \\
\hline Sumber: Data diolah, 2019 &
\end{tabular}


Portofolio saham kelompok PER tinggi periode kepemilikan selanjutnya dan portofolio saham kelompok $P E R$ rendah periode kepemilikan selanjutnya selama tahun 2014-2017 meliputi tiga kali observasi. Observasi pertama dimulai pada tahun 2014 yang membandingkan kinerja portofolio dengan melihat indeks Sharpe portofolio saham kelompok PER tinggi tahun 2014 periode kepemilikan selanjutnya dengan portofolio saham kelompok PER rendah tahun 2015 periode kepemilikan selanjutnya, dilanjutkan hingga observasi terakhir pada tahun 2017.

Tabel 2.

Tabel Indeks Sharpe Portofolio Saham Kelompok PER Tinggi Periode Formasi dan Periode Kepemilikan Tahun 2014-2017

\begin{tabular}{ccc}
\hline Observasi & PER Tinggi \\
& Periode Formasi & $\begin{array}{c}\text { Periode Kepemilikan } \\
\text { Selanjutnya }\end{array}$ \\
\hline 1 & 0,8438 & $-36,3621$ \\
2 & $-36,3621$ & 0,9307 \\
3 & 0,9307 & 0,6887 \\
\hline Sumber: Data diolah, 2019 & &
\end{tabular}

Perhitungan indeks Sharpe pada Tabel 2. menunjukkan bahwa pada observasi 2 kinerja portofolio saham PER tinggi periode tinggi periode kepemilikan selanjutnya lebih rendah dibandingkan dengan kinerja portofolio saham PER tinggi pada periode observasi, namun pada observasi 1 dan observasi 3 mengalami penurunan kinerja pada kepemilikan selanjutnya, sedangkan pada observasi 2 kinerja portofolio saham kelompok PER tinggi periode formasi mengalami peningkatan pada periode kepemilikan selanjutnya.

Perbedaan signifikansi indeks Sharpe antara portofolio saham kelompok PER tinggi periode formasi dengan portofolio saham kelompok PER tinggi periode kepemilikan selanjutnya dianalisis menggunakan uji beda dua rata-rata berpasangan. Pengujian ini dilakukan pada nilai indeks Sharpe portofolio saham kelompok $P E R$ tinggi periode formasi dengan portofolio saham kelompok $P E R$ tinggi periode kepemilikan selanjutnya sebagai ukuran kinerja portofolio.

Tabel 3.

Hasil Uji Beda Dua Rata-Rata Sampel Berpasangan

Portofolio Saham Kelompok PER Tinggi Periode Formasi dan Periode Kepemilikan Tahun 2014-2017

\begin{tabular}{|c|c|c|c|c|c|c|c|c|c|}
\hline & & \multicolumn{5}{|c|}{ Paired Differences } & \multirow[t]{3}{*}{$\mathbf{t}$} & \multirow[t]{3}{*}{ df } & \multirow{3}{*}{$\begin{array}{l}\text { Sig. (2- } \\
\text { tailed) }\end{array}$} \\
\hline & & \multirow[t]{2}{*}{ Mean } & \multirow[t]{2}{*}{$\begin{array}{c}\text { Std. } \\
\text { Deviation }\end{array}$} & \multirow[t]{2}{*}{$\begin{array}{l}\text { Std. Error } \\
\text { Mean }\end{array}$} & \multicolumn{2}{|c|}{$\begin{array}{l}\text { 95\% Confidence } \\
\text { Interval of the } \\
\text { Difference }\end{array}$} & & & \\
\hline & & & & & Lower & Upper & & & \\
\hline $\begin{array}{l}\text { PER } \\
\text { Tinggi }\end{array}$ & $\begin{array}{l}\text { Formasi- } \\
\text { Kepemilikan } \\
\text { Selanjutnya }\end{array}$ &, 052 & 37,250 & 21,506 & $-92,482$ & 92,585 &, 002 & 2 & ,998 \\
\hline
\end{tabular}

Sumber: Data diolah, 2019 
Berdasarkan hasil olahan data menunjukkan nilai sig sebesar 0,998 lebih besar dari taraf sig sebesar $0,05(0,998>0,05)$. Hasil ini berarti tidak ada perbedaan signifikan antara indeks Sharpe portofolio saham kelompok PER tinggi periode formasi dengan portofolio saham kelompok $P E R$ tinggi periode kepemilikan selanjutnya, sehingga hipotesis satu dalam penelitian ini ditolak.

Tabel 4.

Tabel Indeks Sharpe Portofolio Saham kelompok PER Rendah Periode Formasi dan Periode Kepemilikan Tahun 2014-2017

\begin{tabular}{ccc}
\hline Observasi & PER Rendah & $\begin{array}{c}\text { Periode Kepemilikan } \\
\text { Selanjutnya }\end{array}$ \\
& Periode Formasi & $-45,9037$ \\
2 & 0,7024 & $-2,2898$ \\
3 & $-45,9037$ & $-11,7962$ \\
\hline
\end{tabular}

Sumber: Data diolah, 2019

Perhitungan indeks Sharpe pada Tabel 4. menunjukkan bahwa pada observasi 2 kinerja portofolio saham $P E R$ rendah periode kepemilikan selanjutnya lebih tinggi dibandingkan dengan kinerja portofolio saham $P E R$ rendah pada periode formasi, namun pada observasi 1 dan observasi 3 mengalami pembalikan kinerja yang menyebabkan kinerja portofolio saham kelompok PER rendah periode kepemilikan selanjutnya lebih rendah dari periode formasi.

Perbedaan signifikansi indeks Sharpe antara portofolio saham kelompok $P E R$ rendah periode formasi dengan portofolio saham kelompok PER rendah periode kepemilikan selanjutnya dianalisis menggunakan uji beda dua rata-rata berpasangan. Pengujian ini dilakukan pada nilai indeks Sharpe portofolio saham kelompok PER rendah periode formasi dengan portofolio saham kelompok PER rendah periode kepemilikan selanjutnya sebagai ukuran kinerja portofolio.

Tabel 5.

Hasil Uji Beda Dua Rata-Rata Sampel Berpasangan

Portofolio Saham Kelompok PER Rendah Periode Formasi dan Periode Kepemilikan Tahun 2014-2017

\begin{tabular}{|c|c|c|c|c|c|c|c|c|c|}
\hline & & \multicolumn{5}{|c|}{ Paired Differences } & \multirow[t]{3}{*}{$\mathbf{t}$} & \multirow[t]{3}{*}{ df } & \multirow{3}{*}{$\begin{array}{l}\text { Sig. (2- } \\
\text { tailed) }\end{array}$} \\
\hline & & \multirow[t]{2}{*}{ Mean } & \multirow[t]{2}{*}{$\begin{array}{c}\text { Std. } \\
\text { Deviatio } \\
\mathbf{n}\end{array}$} & \multirow[t]{2}{*}{$\begin{array}{l}\text { Std. } \\
\text { Error } \\
\text { Mean }\end{array}$} & \multicolumn{2}{|c|}{$\begin{array}{l}95 \% \text { Confidence } \\
\text { Interval of the } \\
\text { Difference }\end{array}$} & & & \\
\hline & & & & & Lower & Upper & & & \\
\hline $\begin{array}{l}P E R \\
\text { Rendah }\end{array}$ & $\begin{array}{l}\text { Formasi- } \\
\text { Kepemilikan } \\
\text { Selanjutnya }\end{array}$ & 4,167 & 45,346 & 26,181 & $-108,481$ & 116,813 & , 159 & 2 & 888 \\
\hline
\end{tabular}

Berdasarkan hasil olahan data menunjukkan nilai sig sebesar 0,888 lebih besar dari taraf sig sebesar $0,05(0,888>0,05)$. Hasil ini berarti tidak ada perbedaan signifikan antara indeks Sharpe portofolio saham kelompok $P E R$ 
rendah periode formasi dengan portofolio saham kelompok $P E R$ rendah periode kepemilikan selanjutnya, sehingga hipotesis satu dalam penelitian ini ditolak.

Tabel 6.

Tabel Indeks Sharpe Portofolio Saham kelompok PER Tinggi dan PER Rendah Periode Formasi Tahun 2014-2017

\begin{tabular}{ccc}
\hline Observasi & PER Tinggi & PER Rendah \\
\hline 1 & 0,8438 & 0,7024 \\
2 & $-36,3621$ & $-45,9037$ \\
3 & 0,9307 & $-2,2898$ \\
\hline
\end{tabular}

Sumber: Data diolah, 2019

Perhitungan indeks Sharpe pada Tabel 6. menunjukkan bahwa portofolio saham kelompok PER tinggi memberikan kinerja yang lebih baik dibandingkan portofolio saham kelompok $P E R$ rendah pada kondisi periode formasi.

Berdasarkan hasil olahan data, menunjukkan bahwa nilai mean portofolio saham kelompok PER tinggi yaitu $-11,5292$ lebih besar dari nilai mean portofolio saham $P E R$ rendah yaitu $-15,8304 \quad(-11,5292>-15,8304)$. Nilai rata-rata tersebut menunjukkan bahwa kinerja portofolio saham kelompok $P E R$ tinggi lebih baik daripada kinerja portofolio saham kelompok PER rendah pada periode formasi.

Perbedaan signifikansi indeks Sharpe antara portofolio saham kelompok PER tinggi dengan portofolio saham kelompok PER rendah pada kondisi periode formasi dianalisis menggunakan uji beda dua rata-rata independen. Pengujian ini dilakukan pada nilai indeks Sharpe portofolio saham kelompok PER tinggi dengan portofolio saham kelompok $P E R$ rendah sebagai ukuran kinerja portofolio.

Tabel 7.

Hasil Uji Beda Dua Rata-Rata Sampel Independen Portofolio Saham Kelompok PER Tinggi dan PER Rendah Periode Formasi Tahun 2014-2017

\begin{tabular}{|c|c|c|c|c|c|c|c|c|}
\hline \multicolumn{9}{|c|}{ Independent Samples Test } \\
\hline & & \multicolumn{7}{|c|}{ t-test for Equality of Means } \\
\hline & & \multirow[t]{2}{*}{$\mathbf{t}$} & \multirow[t]{2}{*}{ Df } & \multirow[t]{2}{*}{$\begin{array}{l}\text { Sig. (2- } \\
\text { tailed) }\end{array}$} & \multirow[t]{2}{*}{$\begin{array}{c}\text { Mean } \\
\text { Difference }\end{array}$} & \multirow[t]{2}{*}{$\begin{array}{l}\text { Std. Error } \\
\text { Difference }\end{array}$} & \multicolumn{2}{|c|}{$\begin{array}{l}95 \% \text { Confidence Interval } \\
\text { of the Difference }\end{array}$} \\
\hline & & & & & & & Lower & Upper \\
\hline \multirow[t]{2}{*}{$\begin{array}{l}\text { Nilai } \\
\text { PER }\end{array}$} & $\begin{array}{l}\text { Equal } \\
\text { variances } \\
\text { assumed }\end{array}$ & ,220 & 4 & ,836 & 4,301 & 19,519 & $-49,894$ & 58,496 \\
\hline & $\begin{array}{l}\text { Equal } \\
\text { variances not } \\
\text { assumed }\end{array}$ & ,220 & 3,860 &, 837 & 4,301 & 19,519 & $-50,681$ & 59,283 \\
\hline
\end{tabular}

Sumber: Data diolah, 2019

Berdasarkan hasil olahan data, menunjukkan nilai sig sebesar 0,836 lebih besar dari taraf sig sebesar $0,05(0,836>0,05)$. Hasil ini berarti tidak ada perbedaan signifikan antara indeks Sharpe portofolio saham kelompok $P E R$ tinggi dengan portofolio saham kelompok PER rendah pada kondisi periode formasi, sehingga hipotesis tiga dalam penelitian ini ditolak. 
Tabel 8.

Tabel Indeks Sharpe Portofolio Saham Kelompok PER Tinggi dan PER Rendah Periode Kepemilikan Tahun 2014-2017

\begin{tabular}{ccc}
\hline Observasi & PER Tinggi & PER Rendah \\
\hline 1 & $-36,3621$ & $-45,9037$ \\
2 & 0,9307 & $-2,2898$ \\
3 & 0,6887 & $-11,7962$ \\
\hline
\end{tabular}
Sumber: Data diolah, 2019

Perhitungan indeks Sharpe pada Tabel 8. menunjukkan bahwa portofolio saham kelompok PER tinggi memberikan kinerja yang lebih baik dibandingkan portofolio saham kelompok $P E R$ rendah pada periode kepemilikan selanjutnya.

Berdasarkan hasil olahan data menunjukkan bahwa nilai mean portofolio saham kelompok PER tinggi yaitu -11,5809 lebih besar dari nilai mean portofolio saham $P E R$ rendah yaitu $-19,9966 \quad(-11,5809>-19,9966)$. Nilai rata-rata tersebut menunjukkan bahwa kinerja portofolio saham PER tinggi lebih baik daripada kinerja portofolio saham kelompok PER rendah pada periode kepemilikan berikutnya.

Perbedaan signifikansi indeks Sharpe antara portofolio saham kelompok PER tinggi dengan portofolio saham kelompok PER rendah dianalisis menggunakan uji beda dua rata-rata independen. Pengujian ini dilakukan pada nilai indeks Sharpe portofolio saham kelompok PER tinggi dengan portofolio saham kelompok PER rendah sebagai ukuran kinerja portofolio.

Tabel 9.

Hasil Uji Beda Dua Rata-Rata Sampel Independen Portofolio Saham Kelompok PER Tinggi dan PER Rendah Periode Formasi Tahun 2014-2017

\begin{tabular}{|c|c|c|c|c|c|c|c|c|}
\hline \multicolumn{9}{|c|}{ Independent Samples Test } \\
\hline & & \multicolumn{7}{|c|}{ t-test for Equality of Means } \\
\hline & & \multirow[t]{2}{*}{$\mathbf{T}$} & \multirow[t]{2}{*}{ df } & \multirow[t]{2}{*}{$\begin{array}{l}\text { Sig. (2- } \\
\text { tailed) }\end{array}$} & \multirow[t]{2}{*}{$\begin{array}{c}\text { Mean } \\
\text { Difference }\end{array}$} & \multirow[t]{2}{*}{$\begin{array}{l}\text { Std. Error } \\
\text { Difference }\end{array}$} & \multicolumn{2}{|c|}{$\begin{array}{l}\text { 95\% Confidence } \\
\text { Interval of the } \\
\text { Difference }\end{array}$} \\
\hline & & & & & & & Lower & Upper \\
\hline \multirow[t]{2}{*}{$\begin{array}{l}\text { Indeks } \\
\text { Sharpe }\end{array}$} & $\begin{array}{l}\text { Equal variances } \\
\text { assumed }\end{array}$ & ,464 & 4 & ,667 & 8,416 & 18,134 & $-41,933$ & 58,765 \\
\hline & $\begin{array}{l}\text { Equal variances } \\
\text { not assumed }\end{array}$ & ,464 & 3,983 & ,667 & 8,416 & 18,134 & $-42,021$ & 58,852 \\
\hline
\end{tabular}

Sumber: Data diolah, 2019

Berdasarkan hasil olahan data menunjukkan nilai sig sebesar 0,667 lebih besar dari taraf sig sebesar $0,05(0,667>0,05)$. Hasil ini berarti tidak ada perbedaan signifikan antara indeks Sharpe portofolio saham kelompok PER tinggi dengan portofolio saham kelompok $P E R$ rendah, sehingga hipotesis tiga dalam penelitian ini ditolak.

Berdasarkan hasil perbandingan indeks sharpe portofolio saham kelompok $P E R$ tinggi dan portofolio saham kelompok PER rendah pada periode formasi menunjukkan bahwa kinerja portofolio saham kelompok $P E R$ tinggi lebih baik 
dari kinerja portofolio saham kelompok $P E R$ rendah pada kondisi periode formasi. Hasil ini menunjukkan bahwa investor dapat berinvestasi pada portofolio saham dengan membeli saham kelompok PER tinggi karena akan memberikan keuntungan yang lebih tinggi dibandingkan dengan membeli saham kelompok $P E R$ rendah. Saham-saham kelompok PER tinggi yang termasuk ke dalam portofolio optimal pada kondisi periode formasi terdapat 16 saham yaitu : JPRS (Jaya Pari Steel Tbk), INAF (Indofarma Tbk), SMSM (Selamat Sempurna Tbk), KLBF (Kalbe Farma Tbk), WTON (Wijaya Karya Beton Tbk), TRST (Trias Sentosa Tbk), TKIM (Pabrik Kertas Tjiwi Kimia Tbk), JECC (Jembo Cable Company Tbk), VOKS (Voksel Electric Tbk), ALKA (Alaska Industrindo Tbk), UNIT (Nusantara Inti Corpora Tbk), GDST (Gunawan Dianjaya Steel Tbk), SIPD (Siearad Produce Tbk), ULTJ (Ultrajaya Milk Industry and Trading Company Tbk), SMBR (Semen Baturaja Persero Tbk), TPIA (Chandra Asri Petrochemical).

Berdasarkan hasil perbandingan indeks sharpe portofolio saham kelompok $P E R$ tinggi dan portofolio saham kelompok $P E R$ rendah pada periode kepemilikan selanjutnya menunjukkan bahwa kinerja portofolio saham kelompok $P E R$ tinggi lebih baik dari kinerja portofolio saham kelompok $P E R$ rendah pada kondisi periode kepemilikan selanjutnya. Hasil ini menunjukkan bahwa investor dapat berinvestasi pada portofolio saham dengan menjual saham kelompok PER tinggi karena akan memberikan keuntungan yang lebih tinggi dibandingkan dengan menjual saham kelompok PER rendah. Saham-saham kelompok PER tinggi yang termasuk ke dalam portofolio optimal pada kondisi periode kepemilikan selanjutnya terdapat 14 saham yaitu : VOKS (Voksel Electric Tbk), ALKA (Alaska Industrindo Tbk), JPRS (Jaya Pari Steel Tbk), UNIT (Nusantara Inti Corpora Tbk), GDST (Gunawan Dianjaya Steel Tbk), SMSM (Selamat Sempurna Tbk), SIPD (Siearad Produce Tbk), ULTJ (Ultrajaya Milk Industry and Trading Company Tbk), SMBR (Semen Baturaja Persero Tbk), TPIA (Chandra Asri Petrochemical), MAIN (Malindo Feedmill Tbk), KAEF (Kimia Farma Tbk), MYOR (Mayora Indah Tbk), STTP (Siantar Top Tbk).

Hasil uji beda indeks sharpe kedua kelompok portofolio menunjukkan bahwa tidak terdapat perbedaan yang signifikan antara kinerja portofolio saham kelompok $P E R$ tinggi dengan kinerja portofolio saham kelompok $P E R$ rendah pada periode formasi maupun periode kepemilikan selanjutnya. Hasil penelitian ini sejalan dengan penelitian yang dilakukan oleh Mustakawarman dkk. (2016) yang menunjukkan hasil bahwa kinerja portofolio saham $P E R$ rendah mengalami penurunan kinerja pada periode berikutnya, sedangkan portofolio saham $P E R$ tinggi mengalami peningkatan pada periode berikutnya. Fun dan Sautma (2012) dalam penelitiannya pada pasar modal Indonesia menyatakan tidak terdapat perbedaan yang signifikan pada pengembalian portofolio dengan periode kepemilikan 1 tahun.

Hasil penelitian ini tidak mendukung temuan dari Alajbeg et al. (2016) di Kroasia, Chhaya (2015), P. Druv dan Dharmesh (2015), Bodhanwala (2014) di India, Astiti (2014) dan Wiagustini (2008) di Indonesia yang menyatakan bahwa portofolio saham yang dibentuk dari saham dengan $P E R$ tinggi menghasilkan kinerja yang lebih rendah dibandingkan dengan portofolio saham yang dibentuk dari saham dengan $P E R$ rendah. 


\section{SIMPULAN}

Berdasarkan hasil pengujian yang telah dilakukan, maka simpulan yang dapat diambil dari penelitian ini yaitu kinerja portofolio saham kelompok $P E R$ tinggi dan $P E R$ rendah mengalami pembalikan kinerja pada periode kepemilikan selanjutnya. Namun, tidak terdapat perbedaan yang signifikan diantara kedua periode tersebut. Hal ini dilihat dari hasil uji signifikan menunjukkan tidak terdapat perbedaan yang signifikan antara kinerja portofolio saham kelompok PER tinggi dan PER rendah pada periode formasi dengan periode kepemilikan selanjutnya. Jadi pengembalian investasi dengan strategi portofolio kelompok PER tinggi dan PER rendah yang ditahan selama 1 tahun tidak memiliki perbedaan dengan pada saat pembentukannya khususnya pada saham-saham yang terdaftar pada Industri Manufaktur periode 2014-2017.

Kinerja portofolio saham kelompok $P E R$ tinggi lebih baik daripada kinerja portofolio saham kelompok $P E R$ rendah pada kondisi periode formasi dan periode kepemilikan selanjutnya. Berdasarkan hasil tersebut investor dapat berinvestasi pada saham kelompok PER tinggi pada periode formasi dengan memilih saham yang termasuk ke dalam portofolio optimal. Uji signifikan menunjukkan tidak terdapat perbedaan yang signifikan antara kedua portofolio. Jadi pengembalian investasi dengan strategi portofolio kelompok PER tinggi tidak berbeda secara signifikan dengan pengembalian dari investasi dengan strategi portofolio kelompok PER rendah pada kondisi periode formasi dan periode kepemilikan selanjutnya.

Bagi pihak investor dapat menerapkan strategi aktif dalam pembentukan portofolio dengan memilih saham perusahaan yang memiliki kriteria $P E R$ tinggi maupun saham perusahaan dengan kriteria $P E R$ rendah. Memilih saham-saham dengan nilai $P E R$ tinggi maupun $P E R$ rendah akan memberikan pengembalian yang tidak jauh berbeda. Bagi peneliti selanjutnya, dapat meneliti kembali perbandingan kinerja portofolio saham dengan menambahkan pengukuran kinerja lainnya seperti Indeks Treynor dan Indeks Jensen, serta meneliti kinerja portofolio saham dengan pendekatan PER menggunakan periode 3 bulan, dan 6 bulan untuk periode formasi dan periode kepemilikan selanjutnya.

\section{REFERENSI}

Alajbeg, D., Bubaš, Z., \& Švajhler, I. (2016). The P/E Effect On The Croatian Stock Market. International Scientific Publications, 10(1), 84-93.

https://www.scientific-publications.net/get/1000019/1472362411115857\%0 A.pdf $\% 0 \mathrm{~A}$

Anung, R. M. R., Hidayat, R. R., \& Sulasmiati, S. (2016). Penggunaan Analisis Fundamental Pendekatan Price Earning Ratio (PER) Dalam Pengambilan Keputusan Investasi Saham (Studi pada Saham Emiten yang Terdaftar dalam Jakarta Islamic Index Periode 2012-2015), 40(2), 169-176.

http://administrasibisnis.studentjournal.ub.ac.id/index.php/jab/article/view/1 621

Astiti, N. P. Y. (2014). Penilaian Kinerja Portofolio Saham Berdasarkan 
Pendekatan Price Earning Ratio (PER) di Bursa Efek Indonesia. Jurnal Ilmu Manajemen, 4(2), 161-168.

http://ojs.unmas.ac.id/index.php/JUIMA/article/view/107

Bodhanwala, R. J. (2014). Testing the Efficiency of Price-Earnings Ratio in Constructing Portfolio. IUP Journal of Applied Finance, 20(3), 111-118. https://ssrn.com/abstract $=2616595$

Bodie, Z., Kane, A., \& Marcus, A. J. (2014). Manajemen Portofolio dan Investasi (9th ed.). Jakarta: Salemba Empat.

Bondt, W. F. M. De, \& Thaler, R. (1985). Does the Stock Market Overreact? Journal of Finance, 40(3), 793-805.

https://www.jstor.org/stable/2327804

Chen, L., Yu, H., \& Huang, H. (2015). Revisiting The Earnings-Price Effect: The Importance of Future Earnings. Finance Research Letters, 13, 90-96. https://doi.org/10.1016/j.frl.2015.02.009

Chhaya, G., \& Nigam, P. (2015). Value Investing with Price-Earnings Ratio in India. IUP Journal of Applied Finance, 21(2), 34-49. https://ssrn.com/abstract $=2675033$

Druv, N. P., \& Raval, D. D. S. (2015). A Study On Effect of P/E Ratio On Stock Returns. Intercontinental Journal of Finance Research Review, 3(6), 76-90. http://www.icmrr.org/jun_2015/IJFRR/201562009.pdf

Fun, L. P., \& Basana, S. R. (2010). Price Earnings Ratio and Stock Return Analysis ( Evidence from Liquidity 45 Stocks Listed in Indonesia Stock Exchange ). Jurnal Manajemen Dan Kewirauasahaan, 14(1), 7-12. https://doi.org/10.9744/jmk.14.1.7-12

Gunawan, O. V., \& Artini, L. G. S. (2016). Pembentukan Portofolio Optimal Dengan Pendekatan Model Indeks Tunggal Pada Saham LQ-45 di Bursa Efek Indonesia. E-Jurnal Manajemen Unud, 5(9), 5554-5584. https://ojs.unud.ac.id/index.php/Manajemen/article/view/22337

Hartono, J. (2017). Teori Portofolio dan Analisis Investasi (Edisi Kesebelas). Yogyakarta: BPFE.

Houmes, R., \& Chira, I. (2014). The Effect of Ownership Structure on the Price Earnings Ratio - Returns Anomaly. International Review of Financial Analysis, 1-28.

https://doi.org/10.1016/j.irfa.2014.11.017

Huang, A. G., \& Wirjanto, T. S. (2012). Is China's P/E Ratio too Low? 
Examining the Role of Earnings Volatility. Pacific-Basin Finance Journal, 20(1), 41-61.

https://doi.org/10.1016/j.pacfin.2011.07.003

Husnan, S. (2001). Teori Portofolio dan Analisis Investasi. Yogyakarta: UPP AMP YPN.

Kelly, S., \& Mcclean, J. (2008). The low P/E Effect and Abnormal Returns for Australian Industrial Firms. Bond Business School Publications, 1-38. http://dx.doi.org/10.2139/ssrn. 1254643

Lakshmi, V., \& Roy, D. B. (2013). Price Earning Ratio Effect: A Test of the Semi Strong Form of Efficient Market Hypothesis in Indian Stock Market. Indian Institute of Capital Markets, 14(1), 7-12. http://dx.doi.org/10.2139/ssrn.2255389

Levy, M. (2017). Measuring Portofolio Performance: Sharpe , Alpha, or the Geometric Mean? Journal of Investement Management, 15(3), 1-17. http://dx.doi.org/10.2139/ssrn.2837484

Mustakawarman, A. A. N., Wiksuana, I. G. B., \& Artini, L. G. S. (2016). Kinerja Portofolio Saham Undervalued dan Overvalued Pada Indeks LQ45 di Bursa Efek Indonesia. Jurnal Buletin Studi Ekonomi, 21(2), 206-218. https://doi.org/10.24843/bse.2016.v21.i02.p09

Nazwirman. (2008). Penilaian Harga Saham Dengan Price Earning Ratio (PER): Studi Kasus Pada Saham Industri Makanan Dan Minuman Di Bursa Efek Indonesia. Makara Sosial Humaniora, 12(2), 98-106.

https://media.neliti.com/media/publications/4400

Permata, I. S., Kertahadi, \& Topowijono. (2013). Penilaian Saham Dengan Menggunakan Metode Price Earning Ratio (PER) Dan Price Book Value (PBV) (Studi Pada Saham PT Bank Rakyat Indonesia (Persero), Tbk Yang Terdaftar Pada Bursa Efek Indonesia Periode 2003-2012). Jurnal Administrasi Bisnis FIA Universitas Brawijaya, 2(1), 65-73. http://administrasibisnis.studentjournal.ub.ac.id/index.php/jab/article/view/7 4

Rachman, A. A., \& Febrianto, I. (2012). Analisis Kinerja Portofolio Saham Subsektor Perkebunan Dengan Sharpe Measure, Treynor Measure, dan Jensen Measure. Jurnal Ilmiah ESAI, 6(3), 1-7. http://jurnal.polinela.ac.id/index.php/ESAI/article/view/999/685

Rathnasekara, R. D. (2017). Testing Stock Market Efficiency and The Asset Pricing Model : Some Evidence From Sri Lanka. The Journal of Developing Areas, 51(4), 317-330. 
http://doi.org/10.1353/jda.2017.0104

Samsul, M. (2006). Pasar Modal \& Manajemen Portofolio. Jakarta: Erlangga.

Saputro, R. N., \& Badjra, I. B. (2016). Kinerja Portofolio Saham Berdasarkan Strategi Investasi Momentum Pada Industri Manufaktur. E-Jurnal Manajemen Unud, 5(1), 623-649.

https://ojs.unud.ac.id/index.php/Manajemen/article/view/16759

Sari, F. A., \& Nuzul, N. F. (2017). Pembentukan Portofolio Optimal dengan Model Indeks Tunggal (Studi Pada Perusahaan Prhttpoperty, Real Estate And Building Construction Yang Tercatat Di Bursa Efek Indonesia Periode 2013-2015). Jurnal Administrasi Bisnis, 45(1), 1-9.

http://administrasibisnis.studentjournal.ub.ac.id/index.php/jab/article/view/1 745

Sezgin, F. H. (2010). An Empirical Investigation Of The Relationship Among P/E Ratio, Stock Return and Dividend Yields For Istanbul Stock Exchange. International Journal Of Economics and Finance Studies, 2(1), 15-23. http://www.sobiad.org/ejournals/journal_ijef/archieves/2010_1/03

Singgih, M. (2012). Penilaian Kewajaran Harga Saham Sehingga Pertimbangan Investasi Di Bursa Efek Indonesia. Jurnal Bisnis Dan Management, 6(1), 69-78.

https://jurnal.unej.ac.id/index.php/BISMA/article/view/51/28

Sodikin, S., \& Wuldani, N. (2016). Pengaruh Price Earning Ratio (PER) dan Earning Per Share (EPS) Terhadap Return Saham (Studi Pada PT. Unilever Indonesia Tbk. Jurnal Ekonomi Manajemen, 2(1), 18-25.

http://jurnal.unsil.ac.id/index.php/jem/article/view/309

Sugiyono. (2017). Metode Penelitian. Bandung: IKAPI.

Sukmawati, K., \& Kowanda, D. D. (2017). Strategi Investasi Kontrarian Pada Pasar Modal Indonesia : Studi Kasus Saham Liquid Tahun 2008-2012. UG Jurnal, 1-17.

https://library.gunadarma.ac.id/repository/view/3840321

Sunariyah. (2011). Pengantar Pengetahuan Pasar Modal. Yogyakarta: UPP STIM YKPN.

Supriyanto, \& Yani, H. A. (2014). Analisis Kinerja Portofolio Optimal Pada Saham Indeks Bisnis27, JII, LQ45 dan Kompas100 Menggunakan Single Index Model Periode 2010-2012. Journal of Communication Education, $8(2), 1-9$. 
E-Jurnal Manajemen, Vol. 8, No. 10, 2019 : 6301-6321

Suryanto. (2016). Valuasi Saham Dengan Menggunakan Metode Price Earning Ratio (PER) Pada Saham Indeks LQ45. Jurnal AdBispreneur, 1(2), 137144.

Tandelilin, E. (2010). Portofolio dan Investasi Teori dan Aplikasi. Yogyakarta: Kanisius.

Wiagustini. (2008). Profitabilitas Strategi Investasi Kontrarian di Bursa Efek Indonesia. Jurnal Manajemen Dan Kewirausahaan, 10(2), 105-114. https://doi.org/10.9744/jmk.10.2.pp. 105-114

Zabiulla. (2014). Portfolio Strategies of Fund Managers in the Indian Capital Market. IIMB Management Review, 26(1), 28-58.

https://doi.org/10.1016/j.iimb.2013.12.003

Zubir, Z. (2011). Manajemen Portofolio dan Penerapannya dalam Investasi Saham. Jakarta: Salemba Empat. 